\title{
Russia between China and the European Union: Friends or Foes?
}

\author{
Juhan Värk \\ Euroacademy \\ Mustamäe tee 4, \\ Tallinn 10621, Estonia \\ E-mail: juvark@hot.ee
}

Abstract: For a long time Russia has regarded the European Union and China as its main economic and trade partners, giving preference to the EU. A sudden change occurred in October 2008, when as a response to the EU's sharp criticism of the Kremlin over the Georgian-Russian military conflict, Russia decided to re-orient its foreign economic and trade policy from the EU to China and partially also to India. At the same time Russian-Chinese military and energy cooperation started to grow. Russia sold China oil and gas at low price and supplied it with advanced weaponry, which has increased China's aggression toward its neighbours. Russia also started to politically and militarily support China's activities in Syria and Iran, which, in turn, worsened Russia's relations with several EU Member States, including Germany, France and Italy, with whom Russia was planning to cooperate in the developing of the Nord Stream gas pipeline project. However, Russian President Vladimir Putin still declares a great continuing friendship and solidarity with China and is hoping to see the worsening of China's conflict with the US, which, Putin claims, could avert China's direct conflict with Russia. Several leading Russian military and political experts describe this hope as unrealistic. At the same time, the volume of EU-Russian mutual trade was almost 395 billion US dollars in 2011, which exceeds in volume the Chinese-Russian trade volume by more than four times. It shows that Russia's trade reset from the EU to China has been negligible. Also, it is bad news for Russia and China that Iran today stifles cooperation with Georgia and Chinese separatist Uyghurs, and Syrian Bashar al-Assad's regime is developing cooperation with al Qaeda, and does not explain Russia's and China's current similar foreign policy toward Iran and Syria.

Keywords: China, conflict, cooperation, European Union, Russia 


\section{Introduction}

On 27 October 2008 the government of the Russian Federation accepted a document which discussed the basic course of Russia's foreign economic policy up to the year 2020. This document, prepared by the Russian Ministry of Economic Development, foresaw active penetration of the domestic business to the world market. A while later, journalists, having carefully read the document, found to their surprise that it also foresees the essential reorientation of the state's foreign trade from the European Union to China and to some extent to India (NEWSru, 2008). Political observers realized that this was Russia's insult directed at the European Union, who strongly criticized the occupation of South Ossetia and Abkhazia by Russian troops in the recent military conflict between Georgia and Russia. The day the Russian government approved the given document, Chinese Prime Minister Wen Jiabao arrived in Moscow to discuss with the Russian leaders the increasingly close cooperation in the spheres of high technology and oil and gas industry. The article seeks to answer why did the Kremlin make the U-turn in its foreign trade policy, preferring now China to the European Union as its long-time traditional trade partner?

Several Russian and Western political scientists and military experts have warned that a far too euphoric approach towards China and too close relations with it could eventually prove fatal to Russia (Weitz, 2007, p. 55; 2008, p. 63). These aspects will be also looked at in the current article.

\section{China's great power ambitions and real military expenses}

For decades, the People's Republic of China has been one of the leaders of the Third World. Now, during the crisis in global economy China, with its 7 or 8 per cent economic growth per year, tries to show the world that this country must belong to the circle of the leading world-power countries. One expression of such ambitions is the drastic raising of the state's military capacity by the rapid increasing of state military expenses. According to the information of internet portals Regnum and China Today as recently as in 2008 the military expenses of the People's Republic were 61.9 billion US dollars. It exceeded the respective expenses of the previous year, 2007, by 17.6 per cent. During the next three global financial-economic crisis years the growth of these expenses was far smaller and Chinese government itself called the expenses as moderate, claiming that China's military expenses per capita are smaller than in the US, 
UK, France and the Russian Federation (China Today, 2012). At the same time, leading US military analysts claim in the Pentagon's Papers that China's actual military expenses are noticeably larger than what is officially shown. The Stockholm International Peace Research Institute (SIPRI is much more critical, claiming that the People's Republic of China reveals to the public only its direct investments in the state's armed forces and at the same time hides expenses for military research and military procurements (arms, ammunition and technologies) from foreign countries. Due to this, as SIPRI experts suggest, all China's official annual military expenses need to be multiplied by a coefficient of 1.4. (Mills, 2011).

At the same time China's leaders argue that with the continuously increasing military expenses the state's armed forces must be able to successfully stave off all separatists' assaults and attacks from Taiwan, in Tibet and in the province of Xinjiang. China's political and army leaders repeat now quite often that large state military expenses help to balance the military potential of the People's Republic of China and Taiwan, which owing to the great "gift" of arms by the USA in the sum of 6.5 billion US dollars to Taipei in 2008 and similar sums in the following three years, deflected it into great disbalance (China Today, 2012).

Fresh sources of information in China show that at the beginning of 2012 the Chinese government set a goal to modernize the armed forces by 2020. It is remarkable that in 2012 China's annual defense expenditure exceeded, for the first time, 100 billion US dollars (Xinhua, China's defense budget, 2012). However, they represent only a ninth of US defense expenditure. On the other hand, China has today the largest active armed force of more than two million soldiers and officers (Zenko \& Cohen, 2012, p. 87).

\section{Recent changes in the armed forces of the People's Republic of China}

The actual foundation of Red China's military power has been, is now and will be in the future its numerous well-trained ground force. In today's demographic situation, where there are not sufficient brides for the more than 20 million young Chinese men, it is clear that there is more than enough manpower for China's land forces. At the same time, Chinese army leaders tirelessly repeat that irrespective of certain technological backwardness, their land forces with their great manpower are capable of destroying any enemy. Such statements inspire the question as to whom the People's Republic of China then regard as 
their real enemies. Well-known Russian and Western military experts underline that it is possible to determine the weapons and relocation of Red China's army groupings.

The Ministry of Defense of the Russian Federation through Kremlin's internet portal Regnum has revealed to the general public that the most powerful of China's seven military regions have headquarters in Beijing and Shenyang and their troops are being amassed along the border of the Russian Federation. At the same time China's military leaders do not disaffirm that the Beijing Military Region is oriented to the former Siberian Military District of the Russian Federation. The Shenyang Military Region, respectively, is oriented to the Far-Eastern Military District of the Russian Federation. The Beijing and Shenyang military regions have been given direct military command over four of the total of nine China's tank divisions and over six of the total of nine China's mechanized divisions. Also, half of China's twelve tank brigades of the Chinese land forces are located in these military regions. In addition, two tank divisions and one tank brigade were recently relocated to the Lanzhou Military Region, which is oriented towards Central Asia and Siberia's Baikal district. As a result of recent dislocations, the Jinan Military Region (which functions as the strategic reserve for Beijing, Shenyang and Lanzhou) has at its disposal one tank division, one mechanized division, two mechanized brigades and two tank brigades. In addition, the relocating of the $38^{\text {th }}$ Army, which serves as a test bed for the most state-of-the-art military technology in China, to the Beijing Military Region deserves special attention.

According to the estimation of some Russian arms experts and military analysts, the artillery of China's $38^{\text {th }}$ Army is completely automated and exceeds in accuracy that of the Russian Federation. Also, modernization of armour technology is much quicker than in the armed forces of the Russian Federation. China's $38^{\text {th }}$ Army has at its disposal the fully automated $6^{\text {th }}$ tank division, which is equipped with modern Type 96 battle tanks. As a result, the $38^{\text {th }}$ Army's rate of attack is about $1,000 \mathrm{~km}$ per week. It is also worth mentioning that this army has at its disposal the $4^{\text {th }}$ anti-aircraft artillery brigade, which uses modern Russian "Tor" type anti-aircraft missiles. Similar modern military technology still exists in the Nanjing Military Region, which lists in addition to tank and mechanized divisions, an amphibian tank brigade and the only special forces brigade in China.

Compared to the military districts described above, the Chengdu and Guangzhou military regions have substantially weaker military potential. These two regions are oriented towards India and Indo-China states. The regions have no tank 
or mechanized divisions and have recruited and staffed only some motorized infantry divisions. It all shows figuratively that Chinese Army command plans no attack actions on the southern direction ('A Report to US Congress', 2011, pp. 2, 9-45).

During the last few years, Chinese Army command has turned great attention to modernizing their reactive artillery. Respective devices have the calibre range of 273-320 mm (Type-83, A-100, WM-80, WS-1), and their firing power is fully comparable to the famous American MLRS and the Russian Smerch systems. At the same time, the People's Republic has 150 mobile anti-aircraft missile batteries and 15,000 anti-aircraft guns (Chau, 2011; 'China PLA Army Weapons', 2012).

In external sources, the above-mentioned numbers of anti-aircraft weapons are quite modest. Chinese generals, in their informal statements, made no secret about the fact that Russian air force today is near collapse and the People's Republic and their generals are satisfied with their reserved anti-aircraft potential for today and for the nearest future. Chinese Army commanders are complaining only over the lack of attack helicopters.

\section{China's steps to modernize and enlarge its armed forces}

As above facts suggest, during the modernizing of their armed forces, Chinese Army commanders have very carefully kept Russia in focus. In September 2006, the People's Republic of China organized spectacular military manoeuvres, which were conducted over the period of ten days by the Beijing and Shenyan military regions. These military exercises involved a simulation of an invasion up to $1,000 \mathrm{~km}$ across the border into the Russian Federation, along with some encounter battles. The troops were relocated by foot, with the use of motorized vehicles and railway. The leading Russia's military expert Aleksandr Khramtshikhin is convinced that the main goal of these military exercises of such parameter and indicators was to prepare for an offensive war against the Russian Federation. Khramtshikhin argues that China had a good chance to carry out an attack against Kazakhstan, which had the same parameters and indicators. However, locating the Lanchou Military Region anywhere near Kazakhstan was not part of the military exercises.

Why then would China exercise an offensive attack against Russia? Some experts of Chinese problems think that by doing so China strives to pressure 
Russia into better deals of fuel and arms. Other experts agree that this way China will soon be able to legalize the millions of Chinese who up to today have settled in the Russian Far-Eastern areas and the Primorye region and wish to see these areas belong to China in the future. The latter has been repeatedly criticized by the former national security adviser to president Putin, Sergey Prikhodko, who has underlined that the total number of people living in the Siberian region and Russia's Far East today is only 6.7 million and the number of Chinese in the area is negligible (Eesti Päevaleht, 2010). It is very difficult to give a fair evaluation of Prikhodko's claim, because observers who have recently visited the region and have written about it tell otherwise. Whether Chinese are living there as permanent or temporary residents or as tourists, is a complicated question.

\section{How will Russia respond if China continues active military preparations?}

Leaders of the Russian Federation have certainly made efforts to warm the friendship with the People's Republic of China. China has ordered several modern submarines from Russia's military industry and Russia's Ministry of Defense has sold them several used cruisers, helicopters, anti-aircraft missiles and armoured technology. Together with Chinese special forces the Russia's Ministry of Defense organized joint military exercises for the two countries on the territory of the Russian Federation. The most recent joint Chinese-Russian navy exercises took place in April 2012 in the Yellow Sea near Qingdao. Although Russia had brought out its most modern destroyers such as Admiral Tributs, Admiral Vinogradov and Marshal Shaposhnikov together with the missile carrier Varyag and a couple of small ancillary vessels, they were outshone by China's ultramodern aircraft carrier. Therefore after the mentioned navy exercises the leading Russian military expert from the Russian Institute of Political and Military Analysis, Aleksandr Khramtshikhin commented through the internet portal Regnum that the Chinese had used Russians in the joint navy exercises solely to show the world their superiority (Regnum, 2012b). Even in October 2008, at the Moscow meeting, Chinese Prime Minister Wen Jiabao and Russian Prime Minister Vladimir Putin signed an agreement for the construction of a gas pipeline and guaranteeing oil supply in the total amount of 25 billion US dollars.

At the same time the Kremlin has not remained naively waiting for Chinese to warm their "friendliness". Since the beginning of 2004 Russian newspapers Zavtra and Versiya started to spread rumours according to which China had 
directed and adjusted its strategic missiles to the greatest cities of the Russian Federation. China usually strongly protested against such news, but this time remained silent. On 5 August 2009, the Commander-in-chief of the Russian Air Forces Colonel-General Aleksandr Zelin gave a press-conference in Moscow, at which he stressed that a modern space air defense system will be established in the Russian Federation by the year 2020, with an aim to discourage the US and other great powers from deploying space-based weaponry against the Russian Federation. General Zelin added that for the purpose of this system Russia has already designed a next-generation air-defense missile system S-500, which is an upgrade of today's S-400 Triumph, and will be capable of destroying all airborne targets moving at speed up to $5 \mathrm{~km} / \mathrm{sec}$. Simultaneously, Russians are secretly designing and manufacturing the prototype of an ultramodern nextgeneration fighter with radar and anti-aircraft missile control systems (RF DM press release, 2009). In his statement during the press conference, General Zelin never mentioned that the modern and expensive air defense system S-500 could be designed as a defense against China's aggressive plans against the Russian Federation. But later comments to Zelin's statement show that Russian military experts interpreted Zelin's words "to discourage the US and other great powers" as a warning against China's aggression.

Over the course of several years Russia was very interested in cheap Chinese electronics and textile and continued to be interested until August 2012, when Russia joined the World Trade Organization (WTO). Russia's current leader and former Prime Minister Putin in one of his last cabinet sessions in spring 2012 said that following Russia's final joining of WTO, the government must immediately impose emergency measures to resist the flood of cheap import textile from China. He emphasized that branches of Russian strategic industry are, in increasing capacity, in need of affordable Chinese electronics and the government cannot apply protective measures to resist large import flows toward Russia (Direct/NEWS, 2012). At the same time China continues to be very interested in Russian oil, gas and vessels. So today there exists an unconventional balance of interests and seeming friendship between the two great countries. Despite Putin's several recent statements that Russia and China are friendly partners and have developed close cooperation on a wide scale, Russian leaders are quite well informed about the special session of Chinese leaders on 6 December 2011 at which President Hu Jintao commanded Chinese military personnel to prepare for warfare against Russia. The leader of China elaborated that in the coming years China will probably have to fight with its nearest rivalling neighbours Malaysia, the Philippines, Vietnam and, possibly, yet another great country because of its lack of natural resources and free territory 
(Regnum, 2011). President Putin and his entourage resorted to the hope that this unnamed "great country" and enemy to China was the US. But as the visit of Chinese Minister of Defense Liang Guanglie to the US in May 2012 showed, the commercial-economic relations between the two countries continue to toughen, considerably draining the already limited Sino-American trust. After this visit, the Chinese leading newspaper Renmin Ribao voiced that continuous efforts to increase trust between the US and China could avoid a military conflict (Regnum, 2012a). This statement irritated the Kremlin and at the beginning of June 2012 Putin himself came to China on a state visit and to take part in the $12^{\text {th }}$ Shanghai Cooperation Organization summit. On his visit to China Putin emphasized that today's Russian-Chinese relations are free of prejudices and stereotypes (RT: Question more, 2012). As a confirmation, the Russian head of state signed ten important Russian-Chinese agreements in the fields of nuclear energetics, oil and gas, military industry, tourism and high technology. It is noteworthy that in 2011 the Russian-Chinese mutual trade volume increased to a record level of 83.5 billion USD (Zeenews India, 2012), while the Russian-European Union mutual trade volume was 395 billion USD (RF FM Press Release, 2012). This shows that the EU continues to dominate China as Russia's main trade partner.

Although Chinese-Russian relations develop very positively in the area of trade, the Russian military expert Aleksander Sharavin talked about China's military activities to foreign journalists in 2010 in Moscow and said that China has constantly increased its military presence along the border of the Russian Federation, which may lead to a military conflict between the two countries. The popular Russian political observer Andrei Piontkovski added that at that time the Chinese army was capable of performing large-scale ground operations on Russian soil, which were thoroughly practised during manoeuvres. Piontkovski feared that the fate of the Russian Far East would be to serve China's energy and raw materials needs (Eesti Päevaleht, 2010) and also agrees with the general sentiment that Russia and his peaceful partners in the European Union should keep these resources to guarantee their own security. Fortunately Russian government has understood that further implicit support to Iran and Syrian al-Assad's regime, as well as to China, is not justified. Iran, which has recently established close cooperation with Georgia and Syria, declared that they cannot continue to defend the Russian navy base in Tartus against rebel attacks. These facts influence Russia's leaders to change the course of foreign policy toward Iran and Syria. Even Chinese leaders have now understood that implicit supporting of Iran, who cooperate closely with Chinese separatist Uyghurs and the Syrian regime, who, in turn, receive support from al Quaeda, might not be a good idea. 


\section{China's economy reforms after the Communist Party Congress in November 2012}

The $18^{\text {th }}$ National Congress of the Chinese Communist Party, held in early November 2012, was a major event by the standards of the world's biggest political party and second-largest economy. This Congress elected the new top-ranked party leadership with Xi Jinping appointed as the new General Secretary of the Communist Party. The Congress also discussed China's current economic and socio-political situation (Tatlow, 2012), concluding that there are shortcomings in the state's social sphere. China's annual public expenditure on health care was 379 US dollars in 2012, constituting only about a tenth of the OECD average. Despite that, life expectancy in China has risen to 75 years for women and 72 years for men, which is about the average of Southeast Asian countries (BOFIT, 2012b). China's economy is currently in a difficult situation, although the past few months show signs of stabilization. The so-called credit bubble threatens many Chinese commercial banks. Large domestic and Western companies in China are faced with serious problems of environmental protection. In major Chinese cities the average salary of workers continuously rises, exceeding often over 500 euros per month. China thus struggles to remain attractive to Western companies as the country of cheap labour and good trade environment. Several well-known Western companies, among them giant corporations like Google and Toshiba, and surprisingly also some major Chinese corporation, have already left or are leaving China due to these circumstances-Lenovo, for example, is moving its manufacturing to North America (Kuzmina \& Antonov, 2012).

As the new China's Communist Party leader is the son of the famous revolutionary Xi Zhongxun, who was, in turn, a close friend of the former Communist Party progressive leader Deng Xiaoping, it is only logical that $\mathrm{Xi}$ Jinping wishes to adopt the managerial principles of his father's friend. Deng Xiaoping's ideological paradigm, which he formulated in the early 1990s, is as follows: China must observe developments calmly, secure its position, solve problems silently, conceal its capabilities and be patient, be able to keep a low profile and never become a leader (Hanso, 2011; Hiietamm, 2012; Liqun, 2010).

Unfortunately, the former Communist Party leader and China's Premier $\mathrm{Hu}$ Jintao, who left the post in March 2013, has year by year more and more distanced the country from Deng Xiaoping's paradigm in his actions, turning China more aggressive and dangerous to Russia and its other neighbours. Hu Jintao's actions were beginning to resemble Mao Zedong's governing style. So it came as a relief when the new China's Communist Party leader Xi Jinping 
announced to that in the course of his foreign and economic policy he tries to follow Deng Xiaoping's principles (Fenby, 2012). Jinping stressed that China will avoid interventions in the disputed territories or their inclusion and declared economic reforms as the top priority. This suggests that today's China continues on the political level largely following Mao Zedong's principles, according to which political power grows out of a gun barrel (Bishop, 2012).

On 4 December 2012 the Press Secretary of Russian President informed the general public that Putin will visit the EU-Russia summit in Brussels on 21 December as the leader of Eurasian Union. Such entitling may certainly generate some tension in Russian-Chinese relations. Already in 2011, China gave the Russian leadership a clear indication that they will not acknowledge Russia's dominance as a leader in the Shanghai Cooperation Organization projects and in other Eurasian countries' cooperation programs, in which China participates. Political observers from Russia and Western countries agree that the said summit in Brussels covered issues very complicated to both sides, such as the bilateral visa-free regime, the Syrian problem and the implementation of the third energy package of the European Union into EU-Gazprom relations (Sorokin, 2012).

On 28 November 2012, Russian Ambassador-at-Large Anwar Azimov announced in Moscow that from 1 December 2012 Russia will toughen the visa regime for aircrews from the EU countries. The same day, Ekaterina Kuznetsova, director of the Russian Centre of Postindustrial Society, explained to journalists in the press centre Rosbalt that the struggle with the global crisis in the EU will be detrimental to Russia's economy, because all the EU countries in crisis proceed from the understanding that energy resources from Russia must be diminished (Kuznetsova, 2012). According to several political observers (e.g., Remizov from the Moscow State Strategy Institute) such developments will only aggravate problems in EU-Russian relations (Sorokin, 2012), and activate political and economic relations between China and the EU. Bilateral trade volume between China and the European Union, reached 567 billion euros in 2011, which is the highest in the context of the ongoing European Sovereign Debt Crisis. In 2011, China's export to the EU amounted to 356 billion US dollars, showing a 14 per cent growth, and import from the EU was 211 billion US dollars, an increase of 25 per cent. This makes the prospects of China in developing mutual cooperation with the EU fairly favourable. The Kremlin leaders know well that the EU is China's biggest export market, and at the same time China is the EU's biggest import resource (Xin, 2012). The EU-Russian trading relations show the same tendency. In this light, Russian and Chinese leaders know well that their countries need to quickly implement economic reforms to modernize their industries, to fight with corruption, and open their economies for close 
cooperation with the Western countries. To achieve these tasks, both Russia and China must, alongside with other issues, stop the reciprocal accusations about territorial demands, espionage and contraband. Russian government has revealed that their target is to have 80 billion euros (100 billion US dollars) in bilateral Russian-Chinese trade by the year 2015 (Euronews, 2012). China is Russia's rising trade and diplomatic partner but also a neighbour who is getting more and more control over the thinly populated Siberia's resources. China is also interested in the state-of-the-art missiles and helicopters, and in increasing its textile export to Russia. Moscow is unhappy with China's alleged copying of Russian fighter jets and other military hardware (Cheng \& Cohen, 2012). All these developments put new serious problems before Chinese and Russian leaders. Under the circumstances described above, it is clear that in current economic and political conditions it would be more practical for Russia to focus its cooperation efforts first on the European Union. Should Xi Jinping's administration decide to set the planned economy reforms aside and cancel $\mathrm{Hu}$ Jintao's aggressive plans toward the neighbouring countries, it would be a good moment for Russia to stifle its cooperation with China. But now Russia is better off concentrating its cooperation efforts on the European Union.

\section{Conclusion}

For a long time, the European Union has been Russia's most important commercial cooperation partner. This relationship came to a halt shortly after the Russian-Georgian military conflict in 2008, when the European Union sharply criticized Russia over the occupation of South Ossetia and Abkhazia. Resenting the EU's criticism, the Kremlin immediately changed its foreign economic policy to favouring commercial exchanges and cooperation with China instead of the European Union. Unfortunately, China benefitted most from this change, as it could purchase cheap fuel, gas and advanced weaponry from Russia. While Chinese and Russian leaders continue to declare the close friendship and solidarity between the two countries, China is now increasing its military presence along the border of the Russian Far East. Leading Russian military experts agree that the well-armed China is making preparations for warfare and hoping to seize several disputed territories currently owned by its neighbouring countries.

Russian President Vladimir Putin and his entourage have so far refused to open their eyes to this, as they are enthused by China's strong support to the militant 
regimes of Iran and Syria. This, however, has led to exacerbated relations with the larger EU countries with whom the Kremlin wishes to develop the Nord Stream gas pipeline project. Seeing analogous threats, the Russian Prime Minister Dmitri Medvedev has recently started tobility to avoid China's threat to Russia is not realistic. The Kremlin needs to understand that Russia's main enemies are not the US, Georgia, the Baltic States and some other European Union countries, but the main potential threat is coming from China. Most United Nations member states have strongly criticized Russia, following the development of China's foreign and military policies towards Iran and Syria. Even Chinese leaders have now realized that a continuing supporting of Iranian and Syrian regimes is not a promising policy for China, because at the same time these regimes sustain hostility to China's armed forces. Russia is faced with a similar situation with Iran and Syria, and has probably the last good chance to change its foreign policy toward these countries, and China very likely will follow the lead. But the Kremlin also has to know that Russia's chances to successfully re-orient its foreign trade policy from the European Union to China are non-existent. The Kremlin knows well that with its limited resources of oil and gas, Russia very soon cannot satisfy China's increasing demand. At the same time Russia has significant gas delivery obligations before its Nord Stream project partners in the European Union. Also, China's recent great economic growth has now completely stopped and is decreasing. In 2012 China saw the rise of inflation and in the fourth quarter of 2011 the value of China's gold and foreign currency reserves depreciated by about 20 billion US dollars (BOFIT, 2012a). During the period 2007 to 2011 China's commercial banks loan volumes have doubled and the country's banking sector is in an enormous credit bubble. Recent rapid rise in China's economy has created the situation where the majority China's banks might slightly lose their liquidity which would hamper development in China's foreign trade (Äripäev, 2011).

This would also mean that in the nearest future the volume of Russian-Chinese mutual trade volume will remain at the level 4 to 5 times lower than the volume of Russian-European Union mutual trade volume. Quite likely, in the years to come Russia will not be as attractive commercial partner to China as it was a couple of years ago and China will be more and more interested in purchasing high technologies from the European Union. The warn the government of the possible threat coming from China and put a ban on exporting certain modern weapons to China. President Putin's belief in the worsening of SinoAmerican relations and the country's capase developments will probably result in a strengthened cooperation competition between Russia and China over the European Union in some spheres of economy (especially in high technology, 
energy and fuel production). Taking all this into consideration, Russia would benefit the most from resuming closer cooperation with the European Union Member States who make no claims to Russian territories and plan no crafty schemes to snatch Russia's natural resources.

Juhan Värk, PhD (2012) is Professor at the Estonian-American Business Academy and guest lecturer of the Euroacademy. His fields of interest are economic development problems, EU economics, EU-Russia relations and economic security problems. He has been national security and European integration advisor to the Estonian Parliament (Riigikogu), has been working as a consultant in the Estonian Social Affairs Ministry and in some Estonian companies (N-Terminal Group, Ltd., ECO-Group, Ltd., etc.). He has participated in the activities of the Pompidou/INCB work group under the European Council and at the Finnish-Azerbaijan cooperation work group at the Finnish Parliament (Eduskunta) as a foreign expert.

\section{References}

A Report to Congress (2011), Military and Security Developments Involving the People's Republic of China: A Report to Congress Pursuant to the National Defence Authorization Act for Fiscal Year 2010, Washington, D.C.: Office of the Secretary of Defense.

Bishop, B. (2012), 'Welcome to the Xi Jinping Era,' The New York Times, 19 Nov 2012. Retrieved from http://dealbook.nytimes.com/2012/11/19/welcome-to-thexi-jinping-era/ [accessed Nov 2012]

BOFIT (2012a), The Bank of Finland Institute for Economies in Transition Weekly Report on China, Helsinki: BOFIT, 20 Jan 2012.

(2012b), The Bank of Finland Institute for Economies in Transition Weekly Report on China, Helsinki: BOFIT, 30 Nov 2012.

Chau, W. C. H. (2011), 'Explaining China's Participation in Bilateral and Multilateral Military Exercises,' Security Challenges, vol. 7, no. 3, pp. 51-69.

Cheng, J. \& Cohen, A. (2012), 'Russia and China: A NATO of the East?' Al Jazeera English, 7 Jun 2012. Retrieved from http://www.aljazeera.com/programmes/ insidestory/2012/06/20126783558530464.html [accessed Nov 2012]

'China PLA Army Weapons' (2012), China PLA Army Weapons 2012. Images retrieved from http://www.china-defense-mashup.com/chinas-arsenal/china-pla-armyweapons [accessed Aug 2012] 
China Today (2012), Chinese military forces (up to 2012). Retrieved from http://www. chinatoday.com/arm/ [accessed Aug 2012]

Direct/NEWS (2012), 'Putin v panike: Kitai gotovit razrushenije Rossii,' Direct/NEWS, 3 May 2012. Retrieved from http://www.directadvert.ru/news/txt/?id=74761\&da $\mathrm{id}=3299052$ [accessed Aug 2012]

Eesti Päevaleht (2010), 'Venemaa Kaug-Ida massiline hiinastamine on müüt,' Eesti Päevaleht, 27 Oct 2010.

Euronews (2012), 'Russia-China relations.' Euronews, 5 Jun 2012. Retrieved from http:// www.euronews.com/2012/06/05/russia-china-relations/ [accessed Nov 2012]

Fenby, J. (2012), 'Beijing's Dangerous Self-Protection,' The New York Times, 15 Nov 2012. Retrieved from http://www.nytimes.com/2012/11/16/opinion/beijingsdangerous-self-protection.html [accessed Nov 2012]

Hanso, H. (2011), 'Ida uus suurvõim,' Diplomaatia, November 2011, no. 99.

Hiietamm, A. (2012), 'Hiinlane Xi Jinping - tõenäoliselt mõjukaim mees kogu maailmas,' Õhtuleht, 25 Nov 2012.

Kuzmina, N. \& Antonov, M. (2012), 'Amerikanskiie i evropeiskiie proizvoditeli mogut perenesti proizvodstva iz Kitaia v Rossiiu,' Komsomolskaya Pravda, 23 Nov 2012.

Kuznetsova, J. (2012), 'Analitik: Borba ES s krisisom mozhet srikoshetit po Rossii,' MTRK “Mir"- Novosti sotruzhestva, 28 Nov 2012. Retrieved from http://www. mir24.tv/news/economy/6011275 [accessed Dec 2012]

Liqun, Z. (2010), China's Foreign Policy Debates, EUISS Chaillot Papers, no. 121 (Sept. 2010).

Mills, I. (2011), 'A New Era in China-Russian Relations?’ World Politics Review, 18 Oct 2011. Retrieved from http://www.worldpoliticsreview.com/articles/10369/anew-era-in-china-russia-relations [accessed Sept 2012]

NEWSru (2008), 'Ekonomika. Rossiia meniaet orientaciu v ekonomike: ona perenapravit svoi eksport s Evrosoiuza na Indiu i Kitaia,' NEWSru, 27 Oct 2008. Retrieved from http://www.newsru.com/finance/27oct2008/change_print.html [accessed Nov 2008]

Regnum (2011), 'Hu Jintao prikazal VMF Kitaja gotovica k voinie,' IA Regnum, 7 Dec 2011.

_ (2012a), 'Kitai ugrozhaet Amerike “sovokupnoi mashiu”?' IA Regnum, 16 May 2012.

- (2012b), 'O Kitaisko-Russkikh obchikh voienno-morskikh ucheniakh,' IA Regnum, 9 Aug 2012.

RF DM Press Release (2009), Russian Federation Defense Ministry's press release about the press conference of General-Colonel Aleksandr Zelin in Moscow on 5 Aug 2009 (Copy of document).

— (2012), Press release on the statement of Minister of Foreign Affairs of Russia Sergei Lavrov at the "Government hour" in Russia's State Duma, 20 May 2012 (Copy of document). 
RT: Question more (2012), 'Russia and China: new horizons for cooperation,' RT: Question more, 5 Jun 2012. Retrieved from http://www.rt.com/politics/officialword/putin-russia-china-article-997/print/ [accessed Aug 2012]

Sorokin, N. (2012), 'Sammit ES i Rossii budet zanimaca slozhnymi voprosami,' The Voice of Russia, 29 Nov 2012.

Tatlow, D. K. (2012), 'Strongmen Still Cast a Long Shadow in China,'New York Times, 14 Nov 2012.

Weitz, R. (2007), 'China and Russia Hand in Hand: Will it Work?' Global Asia, vol. 2. (2008), China-Russia Security Relations: Strategic Parallelism Without Partnership or Passion? Carlisle, PA: Strategic Studies Institute.

Xin, C. (2012), 'The financial crisis and EU-China trade interdependency,' New Europe, 2 Sep 2012. Retrieved from http://www.neurope.eu/blog/financial-crisis-and-euchina-trade-interdependency [accessed Oct 2012]

Zeenews India (2012), 'China and Russia signed 10 "crucial” agreements,' Zeenews India, 6 Jun 2012. Retrieved from http://www.zeenews.india.com/news/world/ china-and-russia-sign-10-crucial-agreements_780126.html [accessed Aug 2012]

Zenko, M. \& Cohen, M.A. (2012), 'Clear and Present Safety,' Foreign Affairs, March/ April 2012. 